\title{
MANAJEMEN PENDIDIKAN KARAKTER MELALUI PERSPEKTIF ISLAM DALAM MENINGKATKAN DISIPLIN PESERTA DIDIK
}

\section{Bisri Mustofa, Novi Rukhviyanti, Ujang Cepi Barlian}

Universitas Islam Nusantara (UIN) Bandung, Jawa Barat, Indonesia

Email: bisrimustofa654@gmail.com, rukhviyantinovi@gmail.com, ujangcepiberlian@yahoo.co.id

\begin{tabular}{l}
\hline INFO ARTIKEL \\
\hline Diterima \\
28 November 2021 \\
Direvisi \\
15 Desember 2021 \\
Disetujui \\
1 Januari 2022 \\
\hline Kata Kunci: \\
Manajemen \\
Pendidikan \\
Karakter; Perspektif \\
Islam; Fungsi \\
Manajemen \\
Pendidikan Karakter
\end{tabular}

\begin{abstract}
ABSTRAK
Tujuan penelitian ini adalah untuk mengetahui akar masalah pendidikan karakter untuk meningkatkan disiplin peserta didik. Penerapan disiplin ini merupakan permasalahn yang belum terpecahkan sejalan dengan kompleksitas perubahan lingkungan, baik salam sisi perencanaan, pelaksanaan maupun penilaian. Kompleksitas perubahan menyebabkan benturan kepentingan, disorientasi nilai dan fungsi, dan timbulnya konflik. Kompleksitas muncul bersamaan dengan perubahan yang melahirkan perilaku yang liar dan tak terkendali menyebabkan makin melemah dan hilangnya nilai-nilai kebenaran, kejujuran, rasa keadilan, kemanusiaan dan keadaban. Ada beberapa hal yang menjadi munculnya masalah tersebut. Diantaranya belum optimalnya pemberdayaan raw input peserta didik, pemberdayaan instrumental input meliputi kurikulum, belum optimalnya keterlibatan environmental input dan output pendidikan karakter. Penelitian ini berfokus pada masalah yang berkaitan dengan permasalahan perencanaan, pelaksanaan, dan penilaian dalam menejemen pendidikan karakter melalui perspektif islam dalam menigkatkan disiplin peserta didik di SMAN 10 kota Bandung. Adapun kegunaan penelitian ini pertama bertujuan untuk memperoleh gambaran tentang manajemen pendidikan karakter melalui persektif islam dalam meningkatkan disiplin. Selain itu yang kedua adalah untuk untuk mengetahui dan menganalisis perencanaan manajemen pendidikan karakter melalui perspektif islam dalam meningkatkan disiplin. Berdasarkan hasil penelitian SMAN 10 Bandung secara umum dapat ditarik kesimpulan bahwa manajemen pendidikan karakter untuk meningkatkan disiplin peserta didik sudah terlaksana dengan berjalannya fungsi perencanaan, pelaksanaan dan penilaian. Perencanaan pendidikan karakter dituangkan dalam visi dan misi serta tujuan sekolah yang kemudian dituangkan dalam persiapan pembelajaran yang pada dasarnya setiap mata pelajaran memuat materimateri yang berkaitan dengan karakter. Kegiatan penilaian dan evaluasi dilaksanakan pada saat proses pembelajaran berlangsung dan pada akhir pembelajaran.
\end{abstract}

ABSTRACT
The purpose of this study is to find out the root of character education
problems to improve the discipline of learners. The application of this
discipline is an unsolved problem in line with the complexity of
environmental change, both on the planning, implementation and
assessment side. Complexity of change leads to conflicts of interest,
Mustofa, Bisri, Novi Rukhviyanti, Ujang Cepi Barlian (2022). Manajemen Pendidikan Karakter
Melalui Perspektif Islam dalam Meningkatkan Disiplin Peserta Didik, Jurnal Syntax
Transformation, 3(1). https://doi.org/10.46799/jst.v3i1.490
$2721-2769$
Ridwan Institute




\begin{tabular}{ll}
\hline & disorientation of values and functions, and the onset of conflict. \\
& Complexity arises along with changes that give birth to wild and \\
uncontrollable behavior causing further weakening and loss of values \\
of truth, honesty, a sense of justice, humanity and civility. There are a \\
few things that make this problem. Among them is not optimal \\
empowerment of raw input learners, empowerment of instrumental \\
inputs including curriculum, not optimal involvement of environmental \\
input and output of character education. This research focuses on \\
issues related to planning, implementation, and assessment issues in \\
management of character education through an Islamic perspective in \\
enhancing the discipline of learners in SMAN 10 bandung. The \\
usefulness of this research first aims to obtain an overview of \\
Keywords: & character education management through Islamic persupancy in \\
Character & the planning of character education management through an Islamic \\
Education & perspective in improving discipline. Based on the results of SMAN 10 \\
Management; & Bandung research in general, it can be concluded that character \\
Islamic & education management to improve student discipline has been carried \\
Perspectives; & out with the running of planning, implementation and assessment \\
Character & functions. Character education planning is outlined in the vision and \\
Education & mission and goals of the school which is then poured in the \\
Management & preparation of learning which basically each subject contains \\
Function & materials related to character. Assessment and evaluation activities \\
\hline & are carried out during the learning process and at the end of the \\
& learning.
\end{tabular}

\section{Pendahuluan}

Pendidikan merupakan suatu keharusan bagi setiap manusia, sebab melalui proses pendidikan manusia dapat menjadi manusia yang sebenarnya, yakni manusia yang memiliki kualitas dan integritas kepribadian yang utuh (Gunawan, 2012). Keharusan akan pendidikan bagi manusia merupakan refleksi dari karakteristik manusia sebagai homo educandum. Ini berarti bahwa manusia dalam setiap dinamikanya membutuhkan pendidikan. Proses pendidikan yang baik akan menghasilkan manusia yang tumbuh dan berkembang secara sempurna.

Pendidikan karakter merupakan proses yang berkelanjutan dan tak pernah berakhir, sehingga menghasilkan perbaikan kualitas yang berkesinambungan, yang ditujukan pada terwujudnya sosok manusia masa depan, dan berakar pada nilai-nilai budaya bangsa (Sujana, 2019). Pendidikan Karakter merupakayan upaya membantu perkembangan jiwa pada anak-anak baik lahir maupun batih, sehingga menjadikan manusia yang beradab sepertai hormat kepada orang tua, menyayangi yang lebih muda, menghormati pada yang lebih tua, menolong teman, rendah hati, santun, taat beribadah serta jujur apa yang ucapan dan tindakan, selalu berpikir positif, sehingga hidup sesuai dengan ajaran agama dan nilai-nilai budaya bangsanya. Pendidikan karakter harus menumbuh kembangkan nilai-nilai filosofis dan mengamalkan seluruh karakter bangsa secara utuh dan menyeluruh (kaffah). Oleh karena itu pendidikan karakter merupakan bagian integral dari proses pembangunan suatu bangsa di bidang pendidikan yang berkelanjutan.

Menurut (Al-Abrasyi, 1970) dalam hubungannya dengan pendidikan budi pekerti dan pendidikan jiwa, menyatakan bahwa: Proses pembentukan akhlak mulia itu, Islam mempunyai prinsip-prinsip demokrasi, kebebasan, persaudaraan, persamaan dan keadilan dalam rangka membela 
kemanusiaan. Secara lengkap Attiyah mengemukakan prinsip-prinsip ideal pendidikan sebagai berikut: (1) mengajarkan berpikir bebas dan berdiri sendiri dalam belajar, (2) kemerdekaan dan demokrasi dalam mengajar, (3) sistem belajar secara perseorangan, (4) perhatian dan perbedaan individu anak dalam memberikan pelajaran dan mengajar, (5) perhatian terhadap bakat dan kesediaan fitrah anak didik, (6) serta mengetes kecakapan anak, berbicara dengan mereka sesuai akalnya, (7) mempengaruhi mereka secara baik-baik dan dengan rasa kasih sayang, (8) dan memperhatikan pendidikan berpidato, perdebatan-perdebatan, melancarkan berbicara. Yang dikemukakan oleh Attiyah adalah pendidikan yang berwatak humanis, yakni memposisikan manusia sesuai fitrahnya. Itulah paradigma pendidikan yang mampu membangun karakter baik manusia.

Dalam tataran implementatif, paradigma pendidikan humanis yang bersifat filosofis tersebut harus di-break down ke dalam disiplin keilmuan yang lebih konkrit dan aplikatif. Itulah psikologi humanistik yang dikembangkan oleh Abraham Maslow. Frank, G Goble menulis buku dengan judul "Madzhab Ketiga Psikologi Humanistik, Abraham Maslow" menjelaskan tentang bagaimana memandang manusia. Manusia bukanlah suatu gambaran yang partial, tidak lengkap, dan satu sisi, karena dalam hal ini justru akan "mendehumanisasi" dan merampok esensi manusia (Rosyad \& Maarif, 2020).

Pendidikan yang tidak mengembangkan totalitas kemanusiaan, dengan kata lain tidak berlandaskan pada psikologi humanistik, akan mencerabut manusia dari akarnya. Manusia akan kehilangan jati dirinya. Sehingga muncullah karakter bangsa yang tidak diharapkan sebagaimana fenomena kebanyakan masyarakat zaman sekarang. Misalnya munculnya budaya hedonisme, nihilisme, pragmatisme, permisivisme dan liberalisme yang sangat dahsyat mempengaruhi mereka. Budaya-budaya tersebut merambah sampai pada para generasi penerus bangsa. Moralitas telah menjadi barang langka bagi mereka. Motivasi dan semangat hidup meredup. Kegalauan dan kesedihan melanda. Hambatan-hambatan psikhis menghantui pencapaian kebahagiaan dan tujuan hidup. Dasar-dasar kehidupan mengalami kerapuhan.

Karakter dalam agama Islam memiliki pengertian seperangkat sifat kejiwaan yang tertanam sedemikian rupa pada diri manusia, yang menjadi penggeraknya tingkah laku dalam kehidupan; maka istilah keagamaan yang paling sesuai adalah akhlaq yang merupakan bentuk jamak (plural) dari kata khuluq (SUGANDA, 2021).

Akhlak menurut bahasa berasal dari bahasa Arab jamak yang berarti tingkah laku, watak, perangai atau tabiat. Dalam bahasa populer saat ini, akhlak disebut juga dengan kecerdasan emosi (EQ). dimensi spiritual, bahwa akhlak mulia adalah bagian dari iman melahirkan apa yang disebut kecerdasan spiritual (SQ). Sampailah para ahli pun meyakinkan bahwa faktor pencapaian sukses seseorang bukanlah disebabkan oleh kecerdasan intelektual (IQ), melainkan oleh kecerdasan emosi (EQ) dan kecerdasan spiritual (SQ).

Salah satu akhlak yang konsisten dan perlu dipertahankan adalah disiplin. Disiplin pribadi merupakan sifat dan sikap terpuji yang menyertai kesabaran, ketekunan dan lain-lain. Orang yang tidak mempunyai sikap disiplin pribadi sangat sulit untuk mencapai tujuan. maka setiap pribadi mempunyai kewajiban untuk membina melalui latihan, misalnya di rumah atau di masyarakat, anak selain seabgai seorang siswa yang harus memiliki disiplin belajar di sekolah, juga harus memiliki disiplin belajar di rumah mapun di lingkungan masyarakat. Dimana 
anak tersebut tinggal, contohnya anak dapat belajar di masjid, mushola atau yang lainnya.

Pembentukan secara konsisten ini erat kaitannya dengan manajemen diri dan lingkungannya. Seperti pengertian manajemen itu sendiri bahwa manajemen adalah proses perencanaan, pengorganisasian, pengarahan, dan pengawasan usaha-usaha para anggota dan penggunaan sumber dayasumber daya organisasi lainnya agar mencapai tujuan organisasi yang telah ditetapkan (Mustari \& Rahman, 2014).

\section{Menurut (Hendayani,} menyatakan bahwa manajemen merupakan kemampuan pimpinan (manajer) dalam mendayagunakan orang lain melalui kegiatan menciptakan dan mengembangkan kerja sama dalam tujuan organisasi secara efektif dan efisien".

Berdasarkan (Engkoswara, 2001) mengemukakan bahwa "Manajemen dalam arti seluas-luasnya adalah suatu ilmu yang mempelajari bagaimana menata sumber daya untuk mencapai tujuan yang telah ditetapkan secara produktif dan bagaimana menciptakan suasana yang baik bagi manusia yang turut serta di dalam mencapai tujuan yang disepakati bersama".

Dalam mencapai tujuan bersama pun harus berasaskan fungsi-fungsi fundamental. (Suprihanto, 2018) mengungkapkan bahwa fungsi-fungsi fundamental manajemen meliputi empat hal, yaitu: Perencanaan (Planning), pengorganisasian (Organizing), menggerakkan (Actuating), mengawasi (Controlling). Keepat hal diatas tersebut sangat erat kaitannya dengan pedidikan karakter yang efektif dan efisien. Hal ini pun bisa tercipta apabila mampu memanfaatkan sumber daya manusia. Proses ini pun ada dalam pendidikan yang merupakan keseluruhan proses kegiatan bersama. Inilah yang disebut dengan salah satu manajemen pendidikan. Proses manajemen pendidikan memerlukan pendekatan untuk mencapai tujuan diantaranya adalah pendekatan sistem dan pendekatan terpadu. Pendekatan sistem mempelajari manajemen dari sudut sistem, sub sistem, dan komponen sistem dengan penekanan pada interaksi antar komponen didalamnya, sedangkan pendekatan manajemen terpadu dilandasi oleh norma dan keadaan yang berlaku, menelaah ke masa silam serta berorientasi ke masa depan secara cermat.

Pendidikan adalah latihan mental, moral, dan fisik yang bisa menghasilkan manusia berbudaya tinggi. Oleh karena itu, tujuan dan sasaran pendidikan Islam perlu dirumuskan berdasarkan pandangan hidup Islam yang mengarahkan tujuan dan sasaran pendidikan Islam, sehingga manusia harus memiliki pendidikan melalui proses pendidikan Islam agar ia dapat menjadi seorang pemimpin dalam kehidupannya dengan cita-cita dan nilai Islam yang telah menjiwai dan mewarnai corak kepribadiannya (Nata, 2016).

Tujuan pendidikan nasional itu merupakan rumusan mengenai kualitas manusia Indonesia yang harus dikembangkan oleh setiap satuan pendidikan. Oleh karena itu, rumusan tujuan pendidikan nasional menjadi dasar dalam pengembangan karakter bangsa (Omeri, 2015). Menurut (Cahyati et al., 2018) mengklarifikasikan berbagai teori yang berkembang menjadi tiga, yakni: "1) Pendekatan kognitif, 2) Pendekatan afektif, dan 3) Pendekatan perilaku". Kognitif yang tercermin pada kapasitas pikir dan daya intelektualitas untuk menggali dan mengembangkan serta menguasai ilmu pengetahuan dan teknologi. Afektif yang tercermin pada kualitas keimanan, ketakwaan, karakter mulia termasuk budi pekerti luhur serta kepribadian unggul, dan kompetensi estetis. Psikomotorik yang tercermin pada kemampuan mengembangkan keterampilan teknis, kecakapan praktis, dan kompetensi kinestetis.

Ki Hadjar Dewantara dari Taman Siswa di Yogyakarta (1949) pernah berkata 
bahwa "Hidup haruslah diarahkan pada kemajuan, keberadaban, budaya, dan persatuan". Sedangkan menurut Prof. Wuryadi, manusia pada dasarnya baik secara individu dan kelompok, memiliki apa yang jadi penentu watak dan karakternya yaitu dasar dan ajar. Dasar dapat dilihat sebagai apa yang disebut modal biologis (genetik) atau hasil pengalaman yang sudah dimiliki (teori konstruktivisme), sedangkan ajar adalah kondisi yang sifatnya diperoleh dari rangkaian pendidikan atau perubahan yang direncanakan atau diprogram.

Gabungan modal biologis (genetik) dan rangkaian pendidikan ini telah teridentifikasi butir-butir nilai yang dikelompokan menjadi lima nilai utama. Butir-butir nilai nilai-nilai perilaku manusia dalam hubungannya dengan Tuhan Yang Maha Esa, diri sendiri, sesama manusia, dengan lingkungan serta kebangsaan. Deskripsi ringkas mengenai nilai karakter dalam hubungannya dengan Tuhan adalah religius, jujur, bertanggung jawab, bergaya hidup sehat, disiplin kerja keras, percaya diri, berfikir logis, kritis, kreatif, inovatif, mandiri, ingin tahu dan cinta ilmu. Nilai karakter yang hubungannya dengan sesama adalah sadar akan hak dan kewajiban diri dan orang lain, patuh pada aturan-aturan sosial, menghargai karya dan prestasi orang lain, santun dan demokratis. Nilai karakter yang hubungannya dengan lingkungan yaitu peduli sosial dan lingkungan. Sedangkan yang termasuk nilai kebangsaan adalah nasionalis, menghargai keberagaman,

Nilai-nilai karakter tersebut membentuk perspektif pendidikan karakter. Studi J. Mark Halstead dan Monica J. Taylor dalam (Giri, 2018) menunjukkan "bagaimana pembelajaran dan pengajaran nilai-nilai sebagai cara membentuk karakter terpuji telah dikembangkan di sekolah-sekolah di Inggris". Halstead dan Taylor menemukan bahwa nilainilai yang diajarkan tersebut juga disajikan dalam pembelajaran Citizenship, Personal, Social, and Health Education (PSHE) dan mata pelajaran lainnya seperti Sejarah, Bahasa Inggris, Matematika, Ilmu Alam dan Geografi, Teknologi, serta Pendidikan Jasmani dan Olahraga.

Nilai-nilai ini mampu terintegrasi satu sama lain yang menumbuhkan sikap disiplin bagi peserta didik. Dalam kerangka pembangunan dan kemajuan bangsa dan Negara, disiplin sangat penting dan menentukan. Karena kemajuan pembangunan, martabat, dan kesejahteraan bangsa tercapai karena warga masyarakatnya memiliki disiplin yang baik (Robbiyati, 2019). Mengatakan bahwa sikap dan perilaku yang baik dan benar dari penyelenggara Negara beserta seluruh rakyat Indonesia dalam mematuhi dan melaksanakan hukum dan norma kehidupan masyarakat, berbangsa, dan bernegara mempunyai peranan yang sangat penting untuk keberhasilan pembangunan. Penelitian ini bertujuan untuk mengetahui akar masalah pendidikan karakter untuk meningkatkan disiplin peserta didik

\section{Metode Penelitian}

Penelitian ini akan dilakukan dengan menggunakan metode deskriptif. Sebagaimana (Arikunto, 2012) mengemukakan bahwa: "Metode deskriptif adalah metode yang menjelaskan, menggambarkan serta membeberkan sesuatu varaibel masa lalu dan masa sekarang".

Mengingat metode yang akan digunakan dalam penelitian ini adalah metode deskriptif, oleh karena itu dalam penelitian menggunakan pendekatan kualitatif. Penggunaan pendekatan ini disesuaikan dengan tujuan pokok penelitian yaitu untuk menjabarkan dan menganalisis Manajemen Pendidikan Karakter Melalui Perspektif Islam dalam Meningkatkan Disiplin Peserta Didik di SMAN10 Kota Bandung.

Menurut (Darmalaksana, 2020) Penelitian kualitatif digunakan untuk mendapatkan data yang mendalam, yaitu dimana suatu data mengandung makna yang 
sebenarnya di balik data yang tampak. Penelitian kualitatif ditujukan untuk memahami fenomena-fenomena sosial dari sudut pandang subjek penelitian. Dalam penelitian ini digunakan beberapa teknik pengumpulan data yaitu observasi, wawancara, dan studi dokumentasi.

\section{Hasil dan Pembahasan}

Hasil penelitian ini berpedoman pada pertanyaan penelitian sebagai fokus dalam menyajikan hasil penelitian yang merupakan tujuan dari penelitian.

1. Gambaran Tentang Manajemen Pendidikan Karakter Melalui Persektif Islam Dalam Meningkatkan Disiplin.

Fungsi manajemen. Demikian pula dalam pendidikan karakter yang diselenggarakan di sekolah-sekolah formal seperti yang penulis teliti yaitu di SMAN 10 Bandung. Fungsi manajemen yang terdapat dalam pendidikan meliputi fungsi perencanaan atau planning, fungsi pengorganisasian atau organizing, fungsi penggerakan atau actuating, dan fungsi pengendalian atau controlling Adapun gambaran umum tersebut tertuang dalam langkah langkah seperti: kegiatan perencanaan pendidikan karakter peserta didik, kegiatan dalam pelaksanaan program pendidikan karakter, kegiatan dalam penilaian pelaksanaan program pendidikan karakter, faktor pendukung dan penghambat pelaksanaan pendidikan menigkatkan disiplin peserta didik.

Dalam kegiatan perencanaan, perencanaan program pendidikan karakter peserta didik melalui muatan kurikulum. Kurikulum sebagai salah satu perangkat dalam keberlangsungan proses belajar mengajar sehingga perlu dibuat peogram penyempurnaan kurikulum. Program ini terus dilaksanakan dengan memberikan penambahan hal-hal yang terus berkembang untuk proses KBM di dalam kelas. Program pengembangan kurikulum mulai dari perbaikan administrasi pengajaran, metode KBM, penilaian terhadap peserta didik sampai peningkatan disiplin dan penerapan ilmu yang telah dipelajari

Sementara dalam pelaksanaanya, Sekolah mencantumkan nilai-nilai karakter yang akan dikembangkan dalam silabus dan RPP, Begitu juga dalam langkah-langkah proses pembelajaran mencerminkan penanaman nilai karakter kepada peserta didik Para guru, karyawan, para penjaga sekolah dan yang lainya diharapkan menjadi teladan yang baik dalam mengembangkan karakter yang sudah dicanangkan. Sekolah pun menerapkan budaya pembiasaan yang tercermin dalam kehidupan sehari hari disekolah seprti kegiatan pembiasaan spiritual, penanaman nilai tanggung jawab, dan keteladanan.

Dalam penilaian pelaksanaan pendidikan karakter, sekolah menerapkan langkah mulai dari persiapan, pelaksanaan pengolahan sampai pelaporan. Penilaian dilakukan oleh pendidik selama berlangsungnya kegiatan pembelajaran untuk menilai kesiapan, proses, dan hasil belajar peserta didik yang mengarah pada ketercapaian kompetensi yang meliputi sikap, pengetahuan, dan keterampilan. Penilaian tersebut tes dan non tes yang dilakukan melalui ulangan dan penugasan yang tentunya telah terjabarkan dalam rencana pelaksanaan pembelajan

Tentunya dalam proses pelaksaan terdapat factor pendukung dan hambatan yang dialami oleh pihak sekolah dalam mewujudkan pendidikan karakter untuk meningkatkan disiplin peserta didik. Factor pendukung antara lain seperti dukungan yang penuh dari pihak yayasan, kepala sekolah, guru-guru, staf serta orang tua peserta didik yang berkomitmen semuanya untuk menghantarkan putra 
putrinya dalam mengembangkan intelegensi, kreatifitas. Adapun dukungan eksternal seperti instansi-instansi dan lembaga-lembaga secara periodik memberikan bimbingan, arahan serta pelatihan-pelatihan kepada warga sekolah dalam menanamkan nilai-nilai karakter. Sedangkan faktor penghambat yang terjadi seperti ada salah satu peserta yang memang tidak dapat di atur atau tidak dapat memenuhi tata tertib sekolah, faktor orang tua peserta didik yang kurang memperhatikan anak dalam mematuhi peraturan sekolah sehingga berdampak peserta didik tersebut tidak dapat bertanggung jawab pada dirinya sendiri. Selain itu program-program sekolah juga belum teradministrasi dengan baik, dimana administrasi kegiatan sekolah berupa administrasi pelaporan belum di buat dengan baik sehingga untuk pemantauan kemajuan perkembangan penanaman pendidikan karakter kurang terpantau.

2. Analisis Perencanaan Manajemen Pendidikan Karakter Melalui Perspektif Islam Dalam Meningkatkan Disiplin Manajemen Pendidikan Karakter Melalui Pespektif Islam, perencanaan merupakan kegiatan untuk menetapkan tujuan yang akan dicapai, cara-cara dalam mencapai tujuan tersebut, serta merencanakan bagaimana evaluasi terhadap pencapaian tujuan yang direncanakan. Peran kepala sekolah dalam merencanakan implementasi pendidikan karakter di sekolah dari hasil penelitian di SMAN 10 Bandung bahwa kepala bersama stakeholder lainnya telah menuangkan visi, misi dan tujuan sekolah. Di dalam visi yang dimiliki kedua sekolah sudah menggambarkan nilai-nilai karakter yang harus dicapai oleh para peserta didik selama pendidikannya di SMAN 10 Bandung.
Terkait dengan perumusan visi, misi dan tujuan sekolah, tentunya diperlukan kecakapan kepala sekolah merumuskan visi, misi, dan tujuan sehingga mampu meningkatkan keberhasilan sekolah. Sebagaimana firman Alloh dalam QS. Al Hasr: 18 yang artinya "Hai orang-orang yang beriman, bertaqwalah kepada Allah dan hendaklah setiap diri memperhatikan apa yang telah diperbuatnya untuk hari esok (akhirat), dan bertaqwalah kepada Allah, sesungguhnya Allah Maha Mengetahui apa yang kamu kerjakan.”

Visi dan Misi di suatu sekolah adalah merupakan imajinasi moral yang menggambarkan profil sekolah yang diinginkan di masa datang. Imajinasi ke depan seperti itu akan selalu diwarnai oleh peluang dan tantangan yang diyakini akan terjadi di masa datang. Dalam menentukan visi tersebut, sekolah harus memperhatikan perkembangan dan tantangan masa depan. SMAN 10 Bandung telah menuangkan hal ini dalam visi sekolahnya, yaitu dengan mencantumkan keterkaitan pendidikannya untuk menghadapi era globalisasi. Visi, misi dan tujuan itu, perlu dijabarkan secara jeli, tajam dan konkrit dalam berbagai bentuk kegiatan sekolah. Ia mendasari segala bentuk kegiatan yang dilakukan dan dijalankan oleh sekolah tersebut. Dalam perumusannya harus didasari oleh lapisan dalam yang merupakan inti dari sekolah yang terdiri dari :

a. Kepercayaan (faith) seperti hal-hal yang menjadi landasan ideologi dalam kehidupan;

b. Nilai-nilai (values) seperti yang diungkapkan Prof. Dr. Ahmad Sanusi mengenai ke-enam sistem nilai;

c. Filosofi dasar misalnya bahwa pendidikan karakter yang dilandasi dengan filsafat psikologi humanistic. 
d. Pelaksanaan Program Manajemen Pendidikan Karakter Melalui Pespektif Islam.

Peran guru dalam pembentukan karakter tidak hanya sebagai pengajar akademis tetapi juga merupakan pendidik karakter, moral dan budaya bagi peserta didiknya. Implementasi pendidikan karakter dalam pembelajaran secara administratif di SMAN 10 Bandung, telah dilaksanakan oleh semua guru. Namun dalam proses pembelajaran, masih terlihat adanya kecenderungan sebagian guru hanya mentransfer ilmu secara kognitif saja, yang artinya kurang diaplikasikan dalam kehidupan sehari-hari. Adapun kegiatan utama yang dilakukan dalam implementasi pendidikan karakter di SMAN 10 Bandung, yaitu melalui Pembiasan rutin,Integrasi dalam KBM, Kegiatan Spontan, Keteladanan, Kegiatan ko kurikuler dan ekstrakurikuler, dan Kegiatan seharian di rumah dan masyarakat.

Aktifitas pendidikan karakter dilaksanakan melalui kegiatan pembiasaan. Kegiatan ini dilaksanakan oleh semua warga sekolah yang dilakukan secara terus menerus. Sebagaimana yang dikemukakan oleh Ratna Megawangi (2004) yaitu bahwa:

Pendidikan karakter adalah mendidikkan seseorang untuk menjadi terbiasa untuk berprilaku baik, sehingga ia menjadi terbiasa dan akan merasa bersalah kalau tidak melakukann ya. Namun mendidik kebiasaan saja tidak cukup, seseorang yang trbiasa berbuat baik belum tentu menghargai pentingnya nilai-nilau moral. Oleh karena itu, komponen penting yang harus diperhatikan pada pendidikan karakter yaitu bagaimana menumbuhkan rasa keinginan untuk berbuat baik.

Kegiatan pembiasaan merupakan salah satu strategi yang tepat untuk penanaman pendidikan karakter. Pengembangan nilai karakter melalui strategi pembiasaan berbeda antara sekolah yang satu dengan sekolah lainya. Setiap sekolah mengacu pada visi, misi dan tujuan sekolah masing-masing, maka dari itu budaya sekolah mencerminkan ciri khas sekolah. Meskipun sekolah itu sejenis, akan tatapi pembiasaan dan budayamnya akan berbeda, oleh karena itu budaya sekolah merupakan sifat-sifat internal sekolah yang membedakan sekolah yang satu dengan sekolah yang lainnya.

Kemudian kegiatan utama yang dilakukan dalam implementasi pendidikan karakter di SMAN 10 Bandung, yaitu melalui Kegiatan pembiasaan spiritual, Dalam KBM, Penanaman nilai disiplin, Keteladanan, Kegiatan ko kurikuler dan ekstra kurikuler,

3. Penilaian Pelaksanaan Program Manajemen Pendidikan Karakter Melalui Pespektif Islam.

Penilaian merupakan bagian yang sangat penting dalam proses pendidikan. Dalam pendidikan karakter, penilaian harus dilakukan dengan baik dan benar. Penilaian tidak hanya menyangkut pencapaian kognitif peserta didik, tetapi juga pencapaian afektif dan psikomotoriknya. Kegiatan yang dilakukan dalam penilaian pendidikan karakter melalui tahapan sebagai berikut

a. Kriteria Penilaian. Penilaian dilakukan secara kualitatif, serta keberhasilannya lebih ditentukan oleh proses dan keikutsertaan peserta didik,

b. Teknik Penilaian. Penilaian sikap dilakukan melalui observasi, penilaian diri, dan penilaian antara peserta didik. Penilaian keterampilan dilakukan melalui demonstrasi keterampilannya, 
c. Media Penilaian. Dapat berupa jurnal dan portofolio,

d. Proses Penilaian. Proses penilaian dilaksanakan setiap kali latihan dan setiap hari di dalam proses pembelajaran. Dan proses penilaian pendidikan kepramukaan sebagai ekstrakurikuler wajib menitik beratkan pada ranah nilai sikap, keterampilan kepramukaan merupakan pendukung terhadap penilain pendidikan kepramukaan itu sendiri. Proses penilaian sikap dilaksanakan dengan metode observasi, dan dapat dilakukan oleh teman, guru mata pelajaran, pemangku kepentingan atau pembina kepramukaan. Dan terakhir untuk rekapitulasi penilaian dilakukan oleh guru mata pelajaran selaku pembina pramuka.

e. Mekanisme penilaian. Pola implementasi penilaian pada satuan pendidikan meliputi perencanaan program kerja, program latihan, dan pelaksanaan.

f. Faktor Pendukung dan Penghambat Pelaksanaan Manajemen Pendidikan Karakter Melalui Pespektif Islam.

Mewujudkan peserta didik yang berakhlak mulia dan seimbang sesuai dengan kompetensi lulusan melalui pendidika karakter di sekolah bukanlah hal yang mudah. . Dukungan dari orang tua dan lembaga lain dalam melaksanakan kegiatan sekolah dalam rangka implementasi pendidikan karakter merupakan modal besar bagi sekolah.

Hambatan yang terjadi di Sekolah pada umumnya memiliki kesamaan, yaitu belum seluruh orang tua yang mendukung terhadap kegiatan-kegiatan sekolah dalam penanaman nilai karakter kepada anaknya. Selain itu juga masih ada sebagian kecil guru yang masih belum sepenuhnya berkomitmen untuk melaksanakan pendidikan karakter terutama dalam implementasi dalam kegiatan sehari-hari di sekolah. Misalnya masih ada sebagian guru yang belum memberikan teladan yang baik. Namun semua hambatan ini dijadikan sebagai tantangan yang harus dicarikan solusinya. Menurut (Hafidulloh et al., 2021) mengemukakan bahwa "Penciptaan lingkungan yang kondusif bagi perkembangan peserta didik penting, sebab percumah saja anak di sekolah didik tentang nilai-nilai kebaikan, apabila di masyarakat mereka menyaksikan berbagai penyimpangan nilai. Dalam hal ini perlu adanya kebersamaan antara sekolah dengan masyarakat dalam menjunjung tinggi karakter yang baik dan positif sehingga tujuan sekolah maupun tujuan masyarakat dapat diwujudkan dengan sebai-baiknya.

Dengan demikian diharapkan melalui pengembangan nilai-nilai karakter untuk meningkatkan disiplin peserta didik yang diperoleh melalui proses pembelajaran di kelas dan di luar kelas, serta di lingkungan masyarakat sekitarnya, peserta didik diharapkan menjadi manusia yang berkarakter sekaligus memiliki ilmu pengetahuan yang siap dikembangkan pada jenjang pendidikan yang lebih tinggi.

\section{Kesimpulan}

Berdasarkan hasil penelitian SMAN 10 Bandung secara umum dapat di tarik simpulan bahwa manajemen pendidikan karakter untuk meningkatkan disiplin peserta didik sudah terlaksana dengan berjalannya fungsi perencanaan, pelaksanaan dan penilaian. Pengelolaan pendidikan yang efektif dan efisien di SMAN 10 Bandung telah melakukan kerjasama antara kepala sekolah, guru dan komite sekolah. Rencana pendidikan karakter juga tertuang dalam berbagai kegiatan-kegiatan lain di sekolah baik kegiatan pembiasaan, ko kurikuler, ekstrakurikuler baik yang wajib ataupun ekstrakurikuler pilihan. 
Hambatan-hambatan yang terjadi diatasi dengan baik sehingga dapat teratasi dan menunjukkan adanya kemajuan. Kegiatan penilaian dan evaluasi dilakukan melalui pengamatan secara terus menerus, sehingga perkembangan karakter anak dapat diukur melalui perubahan perilaku. Keterlibatan masyarakat dan lembaga yang terkait dalam pendidikan karakter sangat diperlukan terutama untuk mengembangkan potensi-potensi yang ada di sekolah dan dapat menyukseskan program sekolah secara optimal.

Berdasarkan hasil penelitian di atas bahwa fungsi-fungsi manajemen dalam pendidikan karakter menjadi sangat penting demi suksesnya program pendidikan karakter untuk meningkatkan disiplin peserta didik

\section{BIBLIOGRAFI}

Al-Abrasyi, M. A. (1970). Dasar-dasar pokok pendidikan Islam, terj. Bustami A. Gani Dan Djohar Bahry. Jakarta: Bulan Bintang.Google Scholar

Arikunto, S. (2012). Penelitian tindakan kelas. Google Scholar

Cahyati, B., Anwar, K., \& Habibi, M. (2018). Strategi Guru Dalam Meningkatkan Motivasi Belajar Siswa Pada Materi Aqidah Akhlak Di Madrasah Tsanawiyahal-Falah Sukajaya Kecamatan Bayung Lencir Kabupaten Musi Banyuasin Sumatera Selatan. UIN Sulthan Thaha Saifuddin Jambi. Google Scholar

Darmalaksana, W. (2020). Metode Penelitian Kualitatif Studi Pustaka dan Studi Lapangan. Pre-Print Digital Library UIN Sunan Gunung Djati Bandung. Google Scholar

Engkoswara, H. (2001). Paradigma manajemen pendidikan menyongsong otonomi daerah. Yayasan Amal Keluarga. Google Scholar
Giri, I. M. A. (2018). Antisipatif Problematika Pendidikan Berbasis Teknohumanistik dengan Pendidikan Sistem Among Ki Hajar Dewantoro. Maha Widya Bhuwana: Jurnal Pendidikan, Agama Dan Budaya, 1(1). Google Scholar

Gunawan, H. (2012). Pendidikan karakter. Bandung: Alfabeta, 2(1). Google Scholar

Hafidulloh, H., Iradawaty, S. N., \& Mochklas, M. (2021). MANAJEMEN GURU: Meningkatkan Disiplin dan Kinerja Guru. Bintang Pustaka Madani (CV. Bintang Surya Madani). Google Scholar

Hendayani, M. (2019). Problematika Pengembangan Karakter Peserta Didik Di Era 4.0. Jurnal Penelitian Pendidikan Islam,[SL], 7(2), 183-198. Google Scholar

Mustari, M., \& Rahman, M. T. (2014). Manajemen pendidikan. RajaGrafika Persada. Google Scholar

Nata, D. R. H. A. (2016). Ilmu pendidikan islam. Prenada Media. Google Scholar

Omeri, N. (2015). Pentingnya pendidikan karakter dalam dunia pendidikan. Manajer Pendidikan, 9(3). Google Scholar

Robbiyati, N. D. (2019). Korelasi antara motivasi belajar siswa dengan kedisiplinan belajar siswa di MIS Wonoyoso Buaran Pekalongan. IAIN Pekalongan. Google Scholar

Rosyad, A. M., \& Maarif, M. A. (2020). Paradigma Pendidikan Demokrasi Dan Pendidikan Islam Dalam Menghadapi Tantangan Globalisasi Di Indonesia. Nazhruna: Jurnal Pendidikan Islam, 3(1), 75-99. Google Scholar

Suganda, D. P. (2021). Strategi Guru Aqidah Akhlak Dalam Membentuk Karakter 
Manajemen Pendidikan Karakter Melalui Perspektif Islam dalam Meningkatkan Disiplin Peserta Didik

Siswa Pada Kurikulum 2013 Di Mtsn 4 Trenggalek. Google Scholar

Sujana, I. W. C. (2019). Fungsi dan tujuan pendidikan Indonesia. Adi Widya:
Jurnal Pendidikan Dasar, 4(1), 29-39. Google Scholar

Suprihanto, J. (2018). Manajemen. UGM PRESS. Google Scholar

\section{Copyright holder :}

Bisri Mustofa, Novi Rukhviyanti, Ujang Cepi Barlian (2022)

First publication right :

Jurnal Syntax Transformation

This article is licensed under:

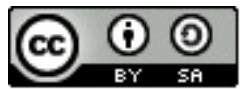

